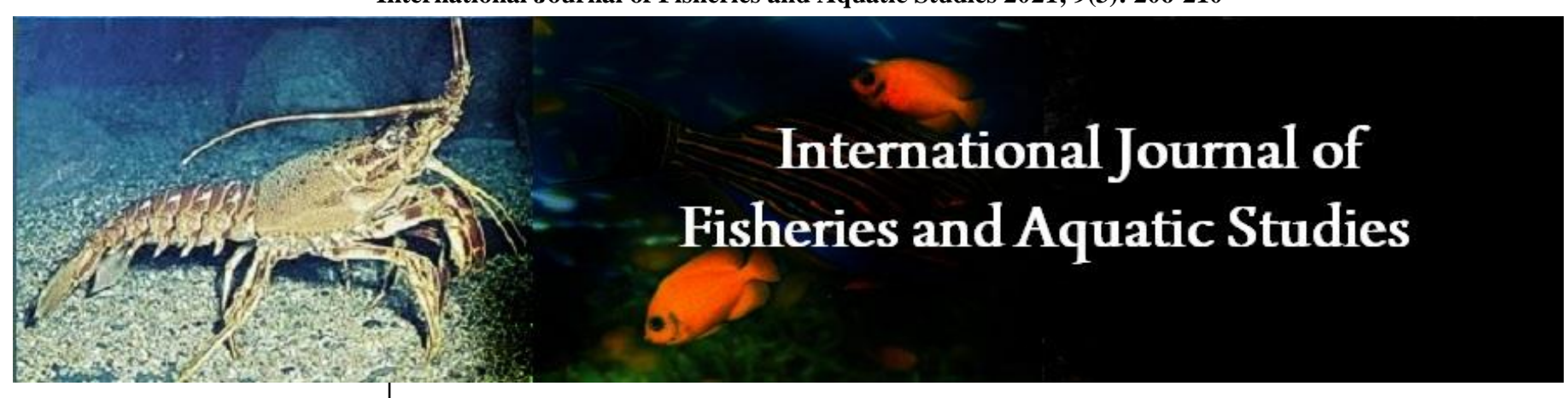

E-ISSN: 2347-5129

P-ISSN: 2394-0506

(ICV-Poland) Impact Value: 5.62

(GIF) Impact Factor: 0.549

IJFAS 2021; 9(3): 206-210

(C) 2021 IJFAS

www.fisheriesjournal.com

Received: 20-03-2021

Accepted: 25-04-2021

Dr. Anita Jhajhria

Associate Professor, Department of Zoology, Shri Kalyan

Government Girls College, Sikar,

Rajasthan, India

\section{Coral reefs of India a review on their status and management}

DOI: https://doi.org/10.22271/fish.2021.v9.i3c.2483

\begin{abstract}
Coral reefs are one of the most ancient and dynamic ecosystems of India. Often referred to as the rainforests of the sea, coral reef ecosystems account for nearly one quarter of the total marine biodiversity, despite only covering $0.2 \%$ of the total seafloor by area. Coral reefs not only provide a sanctuary to a myriad of marine life but also play a key role in protecting the coastline from erosion. People living along the $8,000 \mathrm{~km}$ long coastal stretch of India depend on coral reefs for their livelihood. India is centrally placed within the warm tropical region of the Indian Ocean and exhibits extensive coral reefs in its marine territories. Despite their immense importance, coral reefs are being damaged and destroyed due to natural and anthropogenic activities. The major reef formations in India are restricted to the Gulf of Mannar, Palk bay, Gulf of Kutch, Andaman and Nicobar Islands and the Lakshadweep islands. While the Lakshadweep reefs are atolls, the others are all fringing reefs. Patchy coral is present in the inter-tidal areas of the central west coast of the country.

Coral reefs have been threatened by coral bleaching, ocean acidification, Extreme natural events, coral diseases, unmanaged coral fishing, and anthropogenic activities although laws are sufficient in theory to go for management and protection of the reefs in India. But still these fragile eco-systems are threatened and need to be conserved. It can be achieved by implementing the laws and adopting research oriented activities. The paper reviews the causes and management methods adopted to conserve these biodiversity rich regions.
\end{abstract}

Keywords: Coral reefs, atolls, fringing reefs, coral bleaching and management

\title{
Introduction
}

Coral Reefs are often called the "Tropical Rainforests of the Sea", for their astounding richness of life and extraordinary uniqueness. Being storehouses of immense biological wealth, reefs also provide wide range of economic and environmental services to millions of people around the globe.

Corals belong to the phylum Anthozoa and they are objects of beauty and utility. The hermatypic corals with their symbiotic zoothanllae build the mighty reefs beneath the waves that are exposed only at low tides. Corals are exclusively marine and taxonomically belong to the order scleratinia. They are both solitary and colonial, the solitary forms are called ahermatypes and they do not have symbionts. Reef building corals grow actively in the photic zone of the ocean. Coral reefs are found in the tropical waters as a belt around the globe. Despite their immense importance, coral reefs are being damaged and destroyed at an increasing rate underwater due to both natural and anthropogenic activities. If present rates of destruction are allowed to continue, 90 percent of the reefs will be in danger by 2030 .

Studying the present status of coral reefs and increasing threats to them becomes extremely important. The paper reviews to throw light on the increasing exploitation of coral and analyze the methodology intended for its conservation and management.

\section{Coral reefs in India}

Corresponding Author: Dr. Anita Jhajhria

Associate Professor, Department of Zoology, Shri Kalyan Government Girls College, Sikar, Rajasthan, India

India has a coast line of nearly $8129 \mathrm{~km}$. However, the reef formation is restricted to four major centres

(1) Gulf of Kutch (2) Gulf of Mannar (3) Lakshadweep Islands and (4) Andaman and Nicobar Islands (Fig 1). 


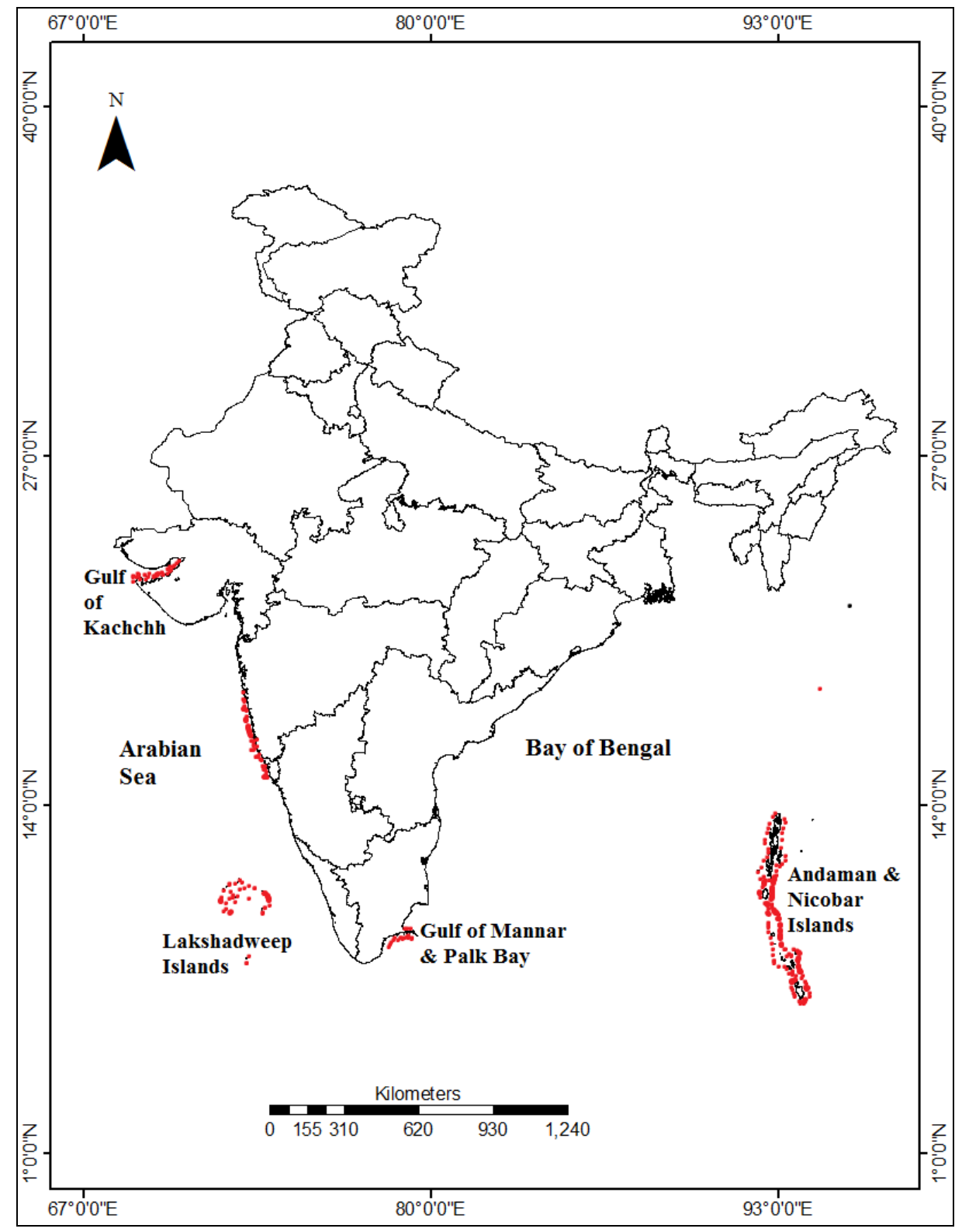

Fig 1: Map depicting Indian coral reefs

The total area of coral reefs in India is estimated to be 2, 375 $\mathrm{Sq}$. Km. The types of reefs include the following

1. Fringing reefs: They are directly attached to the shore and grow towards the sea. These are found in Andaman and Nicobar Islands and Gulf of Mannar.

2. Barrier reefs: are separated from a mainland or island shore by a lagoon and are present in Andaman and Nicobar islands.

3. Atolls: are circular or continuous barrier reefs and extends all the way around a lagoon without a central island. Lakshadweep is the only atoll union territory of India

\section{Ecosystem services of coral reefs}

Coral reefs are very productive ecosystems. Coral reefs are vital to the world's fisheries. They form nurseries for about a quarter of the ocean's fish, and thus provide primary source of protein. They also generate revenue for local communities, national and international fishing fleets.

Coral reefs are often referred as the medicine chests of the sea ${ }^{e e}$. Coral reefs have the potential to provide cures for lifethreatening diseases such as cardio-vascular, ulcers, leukemia, lymphoma and skin cancer. In addition corals unique skeletal structure has been used to make most advanced forms of bone-grafting materials. Coral Reefs are rich in limestone which is often used as a cement substitute in the construction industry. At an industrial level, the coral sand rich in calcium is also a potential raw material for the cement industry ${ }^{[19,20]}$. Healthy reefs act as natural barriers, protecting coastal cities, communities, harbors and beaches from pounding ocean waves and thus prevent erosion, property damage and loss of life. In the Water Filtration Most corals and sponges are filter feeders, which means that they consume particulate matter suspended in the water column. This contributes to enhanced quality and clarity of our near shore waters.

Corals use the dissolved carbon dioxide in the ocean water to form new reefs. This gas conversion to limestone shell controls the carbon dioxide levels in the ocean. Without coral's activity, that gas could saturate the ocean and air mass above it.

It can be seen from Table 1 that the Andaman and Nicobar islands have the largest stretch of coral cover in India. They are not only the largest in terms of area but also rich in diversity. 89 percent of India's Coral diversity is seen in these reefs ${ }^{[12,13]}$. 
Table 1: Status of coral reefs in India

\begin{tabular}{|c|c|c|c|c|}
\hline Particulars & Geographical location & $\begin{array}{l}\text { Area of the reef } \\
\text { (in Sq. Km) }\end{array}$ & $\begin{array}{c}\text { Destruction during } \\
\text { bleaching }\end{array}$ & $\begin{array}{c}\text { Potential for } \\
\text { recovery }\end{array}$ \\
\hline Gulf of Mannar & \begin{tabular}{|c|}
21 islands, South \\
East Coast of India $140 \mathrm{~km}$, \\
between Tuticorin and \\
Rameswaram
\end{tabular} & 94.3 & $\begin{array}{c}60-80 \text { percent loss of live cover. } \\
\text { Only } 25 \text { percent live } \\
\text { corals remaining }\end{array}$ & Medium Low \\
\hline $\begin{array}{l}\text { Gulf of } \\
\text { Kutch }\end{array}$ & $\begin{array}{l}40 \text { islands, Northern side } \\
\text { of Saurashtra peninsula }\end{array}$ & 325.5 & $50-70$ percent & Medium Low \\
\hline $\begin{array}{l}\text { Andaman and Nicobar } \\
\text { Islands }\end{array}$ & 530 islands & 1021.46 & $15-20$ percent & Good \\
\hline Lakshadweep Islands & $\begin{array}{c}\text { Uninterrupted chain of coral } \\
\text { atolls-stretch of } 2000 \mathrm{~km}\end{array}$ & 933.7 & $\begin{array}{c}70-90 \text { percent loss of live } \\
\text { cove }\end{array}$ & Good \\
\hline
\end{tabular}

The coral Biodiversity Reef flats and lagoon shoals dominated by ramose or branching corals. The dominant genera include Porites, Favia, Favites, Goniastrea, Platygyra and Cyphastrea. In Lakshadweep the lagoon reef flats have extensive coverage of Heliopora. Gorgonids are scarce in the shallow waters of our reefs though they are present in deep waters from where they are collected for export. The soft corals or Alcyonarians are dominant among the hard corals in Andaman and Nicobar Islands and they do occur in Gulf of Mannar and Gulf of Kutchh ${ }^{[1]}$.

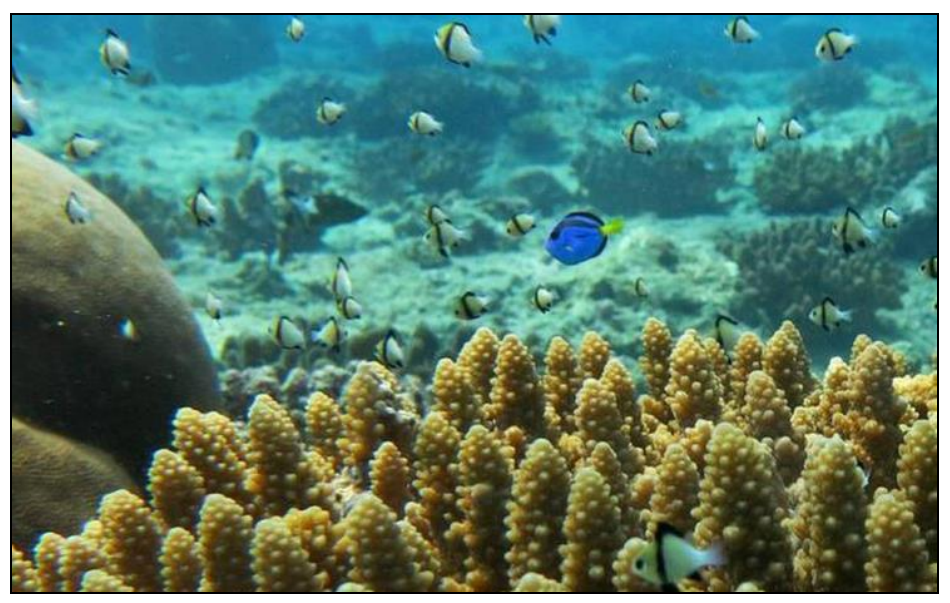

Fig 2: Coral Biodiversity

89 percent of India's Coral diversity is seen in these reefs (Fig 2 ). The flora and fauna reported so far from Indian water include 1284 species of fish, 3271 species of molluscs, 765 species of echinoderms, 519 species of sponges, 345 species of coral belonging to 87 genera, 607 species of crustaceans and 624 species of algae21. Faunal richness in A\&N Islands is remarkably high (6000 species), accounting $7.5 \%$ of total Indian fauna. It is having 478 species, belong to 89 genera and 19 families ${ }^{[5,14]}$. Reef fishes are often one of the most diverse and conspicuous constituents of the reef fauna and because of their wider ecological significance (Fig 3) ${ }^{[21]}$.

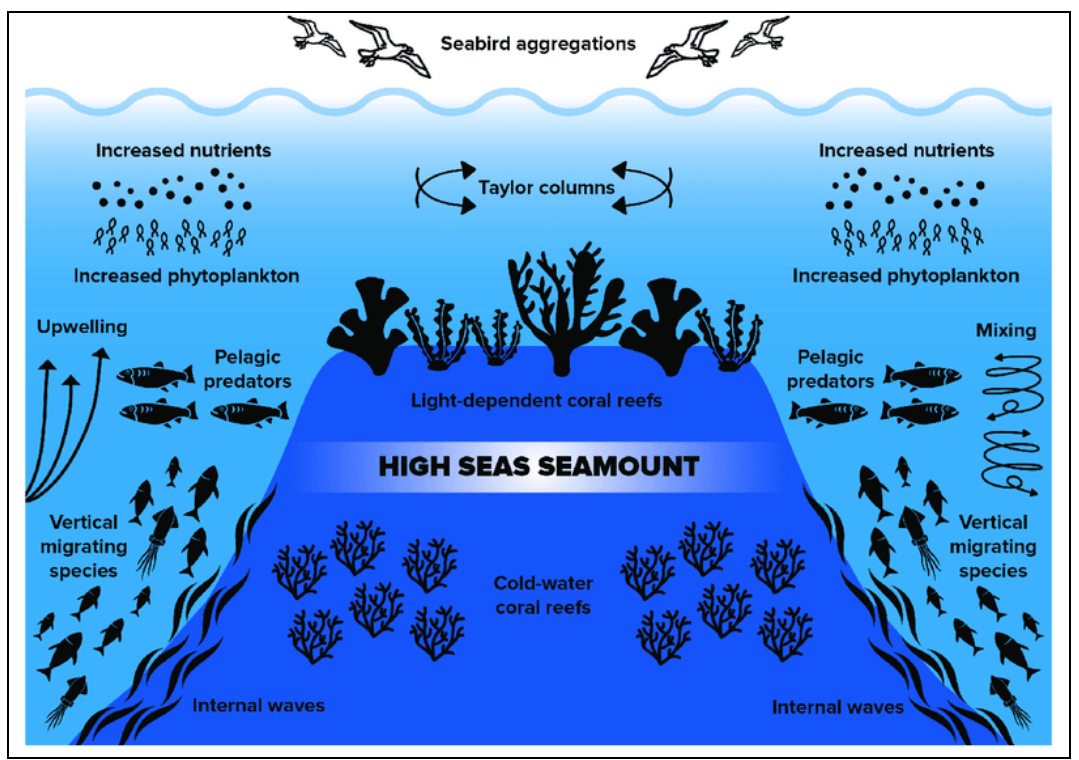

Fig 3: Ecological significance of corals 


\section{Threats to Indian reefs}

Coral Bleaching Coral reefs are highly sensitive and vulnerable to thermal stress, resulting in bleaching events (loss of symbiotic algae) when sea surface temperatures (SST) rise above a threshold Coral bleaching is whiting of coral tissue because of the partial or complete riddance of zooxanthellae symbiont algae population higher irradiance, decreased salinity and metal pollution etc. can cause bleaching; nevertheless, the widely concerned prime cause is the elevated sea surface temperatures triggered by increased global warming ${ }^{[15,18]}$.

\section{Ocean acidification}

Human activities have increased atmospheric concentrations of carbon dioxide $\mathrm{CO}_{2}$ by $36 \%$ and the $\mathrm{pH}$ of ocean surface waters has already declined, The $\mathrm{CO}_{2}$ taken up by the ocean decreases the $\mathrm{pH}$ and concentration of carbonate ions, leads to a combination of chemical changes collectively known as ocean acidification. The effect of elevated $\mathrm{CO}_{2}$ results in decline of calcification rates in corals $[2,3,10,16]$.

\section{Coral disease}

Emergence of different epidemic diseases including White plague, White pox, White band, and Black ban' causes extensive damage to the reef. Recently, a prevalence of white band, white pox, white plague, pink line, pink spot, yellow band, fungal blotch, black band, narcotic patches and coralline lethal orange disease (CLOD) have been reported in Indian Reefs $[4,7,8,17]$.

\section{Reef fishing}

Illegal and destructive fishing practices are also responsible for such type of damage. Many banned malpractices like blast fishing are still going on. Overfishing causes the removal of herbivorous fishes that encourages excessive algal growth in the absence of these grazers. In such a way coral reef ecosystem is shifted to algal dominated barren without any fish and corals. Bio-invasion of macroalgae Kappaphycus alvarezii (Fig 4) and snowflake octocoral Carijoa riisei (Fig 5 ) have caused detrimental impact on reef corals ${ }^{[6,11]}$.

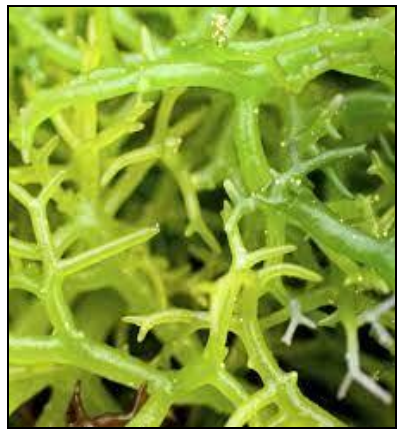

Fig 4: Kappaphycus alvarezii

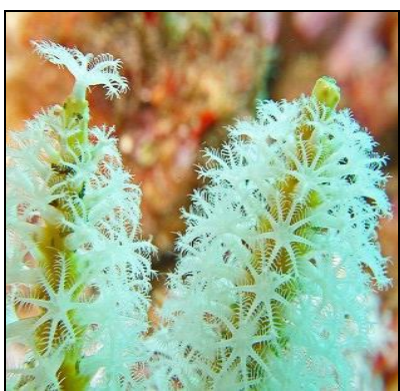

Fig 5: Carijoa riisei

\section{Pest, predator, and competitor}

Outbreak of coral eating Crown of Thorns Starfish Acanthaster plansi and overgrowth of bio-eroding coral boring sponges have been reported from the Indian corals $[9$, 15].

\section{Extreme natural events}

There is a range of natural calamities causing the immense destruction of corals includes cyclone, local tectonic upheavals, tsunami.

\section{Reef tourism}

Uncontrolled tourism may cause major problem responsible for degradation of Indian reefs by causing significant damage to shallow water corals by unintentionally or intentionally trampling and breaking coral fragments.

\section{Anthropogenic activities}

The illegal collection of shells for souvenir hunting, uncontrolled harvesting, smuggling various exotic marine organisms and products derived from the reef is still major problem for Indian reefs.

\section{Efforts in India for conservation of reefs}

Marine parks and biosphere reserves were established. The Gulf of Kutchh Marine Park, in Gujarat, Mahatma Ghandi Marine Park in Wandoor S. Andamans, Gulf of Mannar Biosphere and Jhansi Rani Marine Park in Andaman and Nicobar were established Nodal institutions in these areas were indentified to carry out research and monitoring.

\section{Legislation}

The Govt. of India has promulgated various legislations covering coral reef conservation. All Scleractinians and Gorgonids are brought under wild Life Protection Act. 1972 from July 2001. Conservation of Indian coral reefs is enforced under Marine Fishing Regulation Act (MFRA) 2000 and the Coastal Regulation Zone (CRZ) Notification, 2011; under which coral reefs of India are protected by law. There are total 31 Marine Protected Areas (MPAs) in India among them five coral reef regions have been surveyed and identified for protection.

\section{Recent research for conservation}

Implementation of environmental engineering approaches which focuses on artificial reef restoration methods such as transplantation and underwater silviculture in degraded coral reefs needs to be adopted on a large scale. Reintroduction of species is the practical and effective strategy for conserving these degraded areas.

\section{Conclusion}

Intensive studies on the ecology of Indian coral reef is the need of the hour to avoid extreme risks of destruction by different stressors of the coral reef ecosystem. Future directions should be set up accordingly to overcome the challenges of conserving the Indian coral reefs in ecosustainable way.

\section{References}

1. Adhavan D, Kamboj RD, Marimuthu N, Bhalodi MM. Seasonal variation and climate change influence coral bleaching in Pirotan Island, Gulf of Kachchh Marine National Park, Gujarat, Curr. Sci 2014;107:1780-1781. 
2. Ardron JA, Clark MR, Penney AJ, Hourigan TF, Rowden AA, Dunstan PK. A systematic approach towards the identification and protection of vulnerable marine ecosystems. Mar. Pol 2014;49:146-154.

3. Barnett LA, Baskett M. Marine reserves can enhance ecological resilience. Ecol. Lett 2015;18:1301-1310.

4. Carpenter KE, Abrar M, Aeby G, Aronson RB, Banks S, Bruckner A. One-third of reef-building corals face elevated extinction risk from climate change and local impacts. Science 2008;321:560-563.

5. De K, Venkataraman K, Ingole B Current status and scope of coral reef research in India: A bio-ecological perspective. Indian Journal of Geo Marine Sciences 2017;46(04):647-662.

6. Fridman H, Brêthes JC, Rahmani N, Rinkevich B. Marine silviculture: Incorporating ecosystem engineering properties into reef restoration acts. Ecol. Eng 2015;82:201-213.

7. Gove JM, McManus MA, Neuheimer AB, Polovina JJ, Drazen JC, Smith CR. Near-island biological hotspots in barren ocean basins. Nat. Commun 2016;7:1-8.

8. Guldberg HO, Mumby PJ, Hooten AJ, Steneck RS, Greenfield P, Gomez E. Coral reefs under rapid climate change and ocean acidification. Science 2007;318:17371742 .

9. Hughes TP, Barnes ML, Bellwood DR, Cinner JE, Cumming GS, Jackson JB. Coral reefs in the Anthropocene. Nature 2017a;546:82-90.

10. Jones KR, Klein CJ, Halpern BS, Venter O, Grantham H, Kuempel CD The location and protection status of Earth's diminishing marine wilderness. Curr. Biol 2018;28:2506-2512.

11. Knowlton N. The future of coral reefs. PNAS 98, 54195425.

12. Kumar A, TT, Balasubramanian T. Bleaching of Corals in Agatti Lakshadweep, India: A window view, in: Proceedings of the 12th International Coral Reef Symposium, Cairns, Australia 2012.

13. Pillai CSG. A review of the status of corals and coral reefs of India Indian Journal of Animal Sciences 2010;80(4):53-56.

14. Raj KD, Mathews G, Bharath MS, Edward JKP. Mass mortality of Montipora digitata (Scleractinia) in Vaan Island, Gulf of Mannar, southeast India, Curr. Sci 2016;110:1407-1408.

15. Rajan R, Satyanarayana C, Raghunathan C, Koya SS, Ravindran J, Manikandan B et al. Status and review of health of Indian coral reefs, J Aqua. Bio Fish 2015:3:114.

16. Ravindran J, Kannapiran E, Manikandan B, Murali RM, Joseph A. Bleaching and secondary threats on the coral of Palk Bay: A survey and proactive conservation needs, Indian J mar. Sci 2012;41:19-26.

17. Rowden AA, Stephenson F, Clark MR, Anderson OF, Guinotte JM, Baird SJ. Examining the utility of a decision-support tool to develop spatial management options for the protection of vulnerable marine ecosystems on the high seas around New Zealand. Ocean Coast. Manag 2019;170:1-16.

18. Thangaradjou $T$, Machendiranathan $M$, Ranith $R$, Senthilnathan L, Sasamal SK, Choudhury SB. Coral disease prevalence in Gulf of Mannar and Lakshadweep Islands, Indian J Mar. Sci 2016;45:1755-1762.

19. Thinesh T, Jose AP, Saqib Hassan S, Selvan MK, Selvin
J. Intrusion of coral-killing sponge (Terpios hoshinota) on the reef of Palk Bay, Curr. Sci 2015;109:1030-1032.

20. Venkataraman K, Satyanarayana CH, Alfred JRB, Wolstenholme J. Handbook on Hard Corals of India. Kolkata: Zoological Survey of India 2003, 1-266.

21. Wagner D, Friedlander AM, Pyle RL Brooks CM, Gjerde KM, Wilhelm TA. Coral Reefs of the High Seas: Hidden Biodiversity Hotspots in Need of Protection Front. Mar. Sci 2020;7:1-13. 